\title{
Morphological changes and parasite load of the adrenal from dogs with visceral leishmaniasis
}

\author{
Alterações morfológicas e carga parasitária da adrenal de cães com leishmaniose visceral \\ Claudia Momo ${ }^{1}$; Nathália Alves de Souza Rocha ${ }^{2}$; Pamela Rodrigues Reina Moreira ${ }^{1}$; Danísio Prado Munari ${ }^{3}$; \\ Suely Regina Mogami Bomfim²; Daniela Bernadete Rozza²; Rosemeri de Oliveira Vasconcelos ${ }^{1 *}$ \\ ${ }^{1}$ Departamento de Patologia Veterinária, Faculdade de Ciências Agrárias e Veterinárias - FCAV, \\ Universidade Estadual Paulista - UNESP, Jaboticabal, SP, Brasil \\ ${ }^{2}$ Departamento de Apoio, Produção e Saúde Animal, Faculdade de Medicina Veterinária de Araçatuba - FMVA, \\ Universidade Estadual Paulista - UNESP, Araçatuba, SP, Brasil \\ ${ }^{3}$ Departamento de Ciências Exatas, Faculdade de Ciências Agrárias e Veterinárias - FCAV, Universidade Estadual Paulista - UNESP, \\ Jaboticabal, SP, Brasil
}

Received July 17, 2013

Accepted January 30, 2014

\begin{abstract}
The objective of this study was to analyze morphological changes and parasite loads in the adrenal gland from 45 dogs with visceral leishmaniasis (VL). The animals were from the Zoonosis Control Center of Araçatuba, state of São Paulo, which is an endemic region for the disease. These animals were euthanized due to positive diagnoses of VL. The dogs were classified into asymptomatic, oligosymptomatic and symptomatic groups. The parasite load was determined by immunohistochemistry, using VL-positive dog hyperimmune serum. Nine dogs showed an inflammatory infiltrate composed, predominantly, of plasma cells and macrophages. However, only eight dogs showed macrophages with amastigote forms of the parasite, immunolabeled in the cytoplasm. The medullary and reticular layers were the most affected areas, possibly due to a favorable microenvironment created by hormones in these regions. The density of parasites in the glandular tissue was not associated with clinical signs of VL $(\mathrm{P}>0.05)$. However, the presence of the parasite was always associated with the presence of a granulomatous inflammatory infiltrate. This gland may not be an ideal place for the parasite's multiplication, but the presence of injuries to the glandular tissue could influence the dog's immune system, thus favoring the parasite's survival in the host's different organs.
\end{abstract}

Keywords: Leishmania infantum chagasi, adrenalitis, dog, immunohistochemistry.

\section{Resumo}

O objetivo deste estudo foi analisar as alteraçóes morfológicas e a carga parasitária da glândula adrenal de 45 cães com leishmaniose visceral (LV). Os animais eram provenientes do Centro de Controle de Zoonoses (CCZ) de Araçatuba (SP), região endêmica para a doença. Esses animais são submetidos à eutanásia, devido ao diagnóstico positivo para LV. Os cães foram classificados nos grupos assintomático, oligossintomático e sintomático. A determinação da carga parasitária foi feita por imuno-histoquímica, com utilização de soro hiperimune de cão positivo para LV. Em nove cães, verificou-se um infiltrado inflamatório, composto predominantemente por plasmócitos e macrófagos. Entretanto, apenas oito cães apresentaram macrófagos com formas amastigotas do parasito imunomarcadas em seu citoplasma. As camadas medular e reticulada foram as mais afetadas, possivelmente por um microambiente favorável criado pelos hormônios nestas regióes. A densidade de parasitos no tecido glandular não foi relacionada com os sinais clínicos de LV $(\mathrm{P}>0,05)$. No entanto, a presença do parasito sempre esteve associada à presença de infiltrado inflamatório granulomatoso. Possivelmente, essa glândula não é um sítio ideal para a multiplicação do protozoário, mas a presença de injúrias no tecido glandular poderia influenciar o sistema imune do cáo, favorecendo a sobrevivência do parasito nos diferentes órgãos do hospedeiro.

Palavras-chave: Leishmania infantum chagasi, adrenalite, cão, imuno-histoquímica.

\footnotetext{
${ }^{*}$ Corresponding author: Rosemeri de Oliveira Vasconcelos

Departamento de Patologia Veterinária, Faculdade de Ciências Agrárias e

Veterinárias - FCAV, Universidade Estadual Paulista - UNESP,

CEP14884-900, Jaboticabal, SP, Brasil

e-mail: rosevasc@fcav.unesp.br
} 


\section{Introduction}

Visceral leishmaniasis (VL) is a very important zoonosis concerning public health, caused by the Leishmania (Leishmania) infantum chagasi protozoon. Brazil is the Latin American country that presents the highest number of human cases with the disease. In the state of São Paulo, since 1994, high incidence of VL cases has been reported among humans and in the canine population. The main control measure so far has been to euthanized seropositive dogs, but this method has not been effective in controlling the disease and there has not been a decrease in the number of human cases (BRASIL, 2006).

VL is transmitted among vertebrate hosts through the Lutzomyia longipalpis sand fly female's sting, during its blood meal (PEREIRA, 2000). In the domestic environment, dogs are considered to be the main reservoir of the protozoon that causes $\mathrm{VL}$, which makes it more difficult to control the disease (BRASIL, 2006).

Leishmania sp. has the ability to escape from the immune system, due to its resistance to phagocytosis (VIRELLA, 2001). As a result, these parasites stimulate chronic inflammation, initially characterized by the presence of granulocytes, followed by the proliferation of macrophages, lymphocytes and natural killer cells (NK), which together form granulomas (VIRELLA; BIERER, 2001).

A variety of clinical signs have been described in dogs, and these animals can be characterized as asymptomatic or symptomatic, presentation of more advanced signs of the disease, such as skin lesions (ulcerations, desquamation and alopecia), progressive weight loss, onychogryphosis, hepatomegaly and splenomegaly, glomerulonephritis and hematological alterations (anemia, leucopenia and thrombocytopenia) (FEITOSA et al., 2000).

The animals that are considered to be susceptible to this infection are the ones that present lesions in their organs of great severity and density caused by parasites, including the skin. They also present variations in their cytokine profile in response to the parasite, with predominance of a Th2 type response and humoral immunity, which has little effectiveness in controlling the protozoon (GINN et al., 2007).

The most frequent histopathological finding among dogs with $\mathrm{VL}$ is chronic inflammation of organs such as skin, liver, kidneys, lymph nodes and adrenal glands, among others. Macrophages predominate and, in some cases, contain amastigote forms of the parasite (LONGSTAFFE; GUY, 1985; LIMA et al., 2004; GIUNCHETTI et al., 2008; MOREIRA et al., 2010).

The adrenal glands are composed of two endocrinal glands that are embryologically and functionally independent, divided into cortical and medullary layers (CARLTON; McGAVIN, 1998). The adrenal cortex is composed of steroid-secreting cells and is divided into three layers: the glomerulosa, fasciculata and reticularis zones (HIB; FIORI, 2003). The glomerulosa zone is formed by cells that secrete mineralocorticoids, such as aldosterone. The fasciculata zone is responsible for secretion of glucocorticoids (cortisol) and gonadocorticoids. Finally, the reticularis zone is formed by cells that secrete gonadocorticoids, estrogen and progesterone. The medullary adrenal layer is formed by chromaffin cells (pheochromocytes), which produce catecholamines, epinephrine and norepinephrine, and are responsible for increasing or maintaining blood pressure (BANKS, 1992).

The adrenal gland has an essential role in the organism's response to immune stress, since it is practically the exclusive source of corticosteroids in the organism (DAVIES; MACKENZIE, 2003). There is evidence that suggest that inflammatory messengers influence the release of stress hormones by the adrenal gland. Agents that cause systemic inflammation activate an intrinsic circuit for inflammatory regulation, which can influence the adrenal gland's response to immune stress (ENGSTRÖM et al., 2008).

Infections in the adrenal gland can cause tissue damage, directly or indirectly, as well as alterations to its endocrine function. The direct damage occurs through microbes' multiplication and local production of toxins, while the indirect damage is caused by alterations to immunological regulation and regulation of the endocrine mediators (BOSWORTH, 1979). Different experimental infection models have shown that imbalance in the hypothalamicpituitary-adrenal axis (HPA) impairs the host from having an adequate immune-endocrine response, which can influence its susceptibility to diseases (RUIZ et al., 2003).

Adrenal infections have great relevance, but they are not identified in an effective manner during clinical examinations on animals. This gland can be infected by a great number of pathogenic agents, such as fungi, viruses, parasites and bacteria (ARLT; ALLOLIO, 2003). Among these, there have been reports on Microsporidia spp. (TOSONI et al., 2002), Paracoccidioides brasiliensis (PEREIRA et al., 2006) and Leishmania sp. (SCHNUR et al., 1973; GIBSON-CORLEY et al., 2008). Pumarola et al. (1991) and Toplu and Aydogan (2011) described necrotizing vasculitis in several organs of dogs with VL, including the adrenal gland. Ferrer et al. (1998) and Tafuri et al. (2001) reported that infection by Leishmania sp. in the adrenal gland was not easily diagnosed, due to the small number of parasites present in the organ. Hofman et al. (2000) reported occurrences of infection in the adrenal gland of humans, caused by Leishmania sp., among HIV-positive individuals.

Some variants, such as tropism due to pathogenic agents, gland anatomy and the individual's immune state, contribute towards the progression and establishment of adrenal gland dysfunction. In order for an individual to manifest clinical signs that indicate adrenal disorders, it is necessary for 80 to $90 \%$ of the gland to be affected in humans (PAOLO JR; NOSANCHUK, 2006).

There are few reports on the infectious processes and inflammatory response of the adrenal gland. The scientific articles that discuss canine visceral leishmaniasis just quote the adrenal gland as a secondary target organ, but no eloquent description of the main lesions or their pathogenesis is found (GIBSONCORLEY et al., 2008). The objective of the present study was to analyze the main morphological alterations of the adrenal gland and to quantify the parasite load among dogs with VL.

\section{Materials and Methods}

Forty-five VL serological positive dogs, from the Zoonosis Control Center of Araçatuba, state of São Paulo, which is an endemic area for VL, were euthanized and used in the study. 
They were classified as symptomatic (29 dogs), oligosymptomatic (seven dogs) and asymptomatic (nine dogs) (BRASIL, 2006). The adrenal glands were collected during the necropsy, fixed in a solution of $10 \%$ formol, buffered with phosphates ( $\mathrm{pH} 7.2$ ), and were processed through embedding in paraffin and staining with hematoxylin and eosin.

The parasite load was determined by means of the immunohistochemical technique, on paraffin-embedded sections, using hyperimmune serum from a VL-positive dog, in accordance with the protocol described by Tafuri et al. (2004), and modified by Moreira et al. (2013), at a dilution of 1:1000. In order to determine the density of cells immunolabeled for the parasite, parasitized macrophages were counted in five fields with a $40 \mathrm{x}$ objective lens, therefore, obtaining a mean per animal. The data was analyzed through the Kruskal-Wallis statistical test and the groups were compared by the Dunn's multiple comparison test $(\mathrm{P}<0.05)$, using the GraphPad Prism software (version 4.0, 2003).

\section{Results}

Out of a total of 45 analyzed dogs, eight presented macrophages immunolabeled with amastigote forms of Leishmania infantum chagasi in their cytoplasm: six dogs were symptomatic (with $71,9 \pm 23,9$ mean and standard deviation of the immunolabled cells), one oligosymptomatic (mean 5,6) and one asymptomatic (mean 0,2); all of them with inflammatory infiltrate composed of plasmocytes and macrophages. In the groups of asymptomatic, oligosymptomatic and symptomatic dogs, respectively, there were one, one and six dogs with immunolabeled parasites in the adrenal gland. There was not a significant statistical difference in the density of parasitized macrophages $(\mathrm{P}>0.05)$ among the groups of dogs. In 20 dogs, the predominant inflammatory infiltrate in the adrenal gland was composed of plasmocytes and macrophages. However, six of these dogs (all of them symptomatic) presented the granulomatous inflammation commonly observed in VL (Figure 1). The cortical and medullary layers were affected. The reticularis and medullary zones and/or the transition between them or between the reticularis and fasciculata zones, were the preferred locations for inflammation and localization of the parasite. Occasionally, only the fasciculata layer was involved. The animals with negative immunolabeling for Leishmania spp. also presented inflammatory infiltrate in the adrenal gland. The inflammatory infiltrate in these cases was of mild intensity, characterized by rare leukocytes in the cortical's interstices or medullary layers.

\section{Discussion}

The animals studied, both with and without clinical signs of VL, showed involvement of the adrenal gland, with detection of inflammation and the protozoon Leishmania sp.

In the present study, the areas most affected by inflammation or by the parasite were the reticularis and the medullary layers, which were possibly more favorable for the parasite. Carvalho et al. (2008) reported inflammation in these same layers, but they did not observe parasites in the adrenal glands of mice experimentally infected with L. amazonensis. Toplu and Aydogan (2011) also
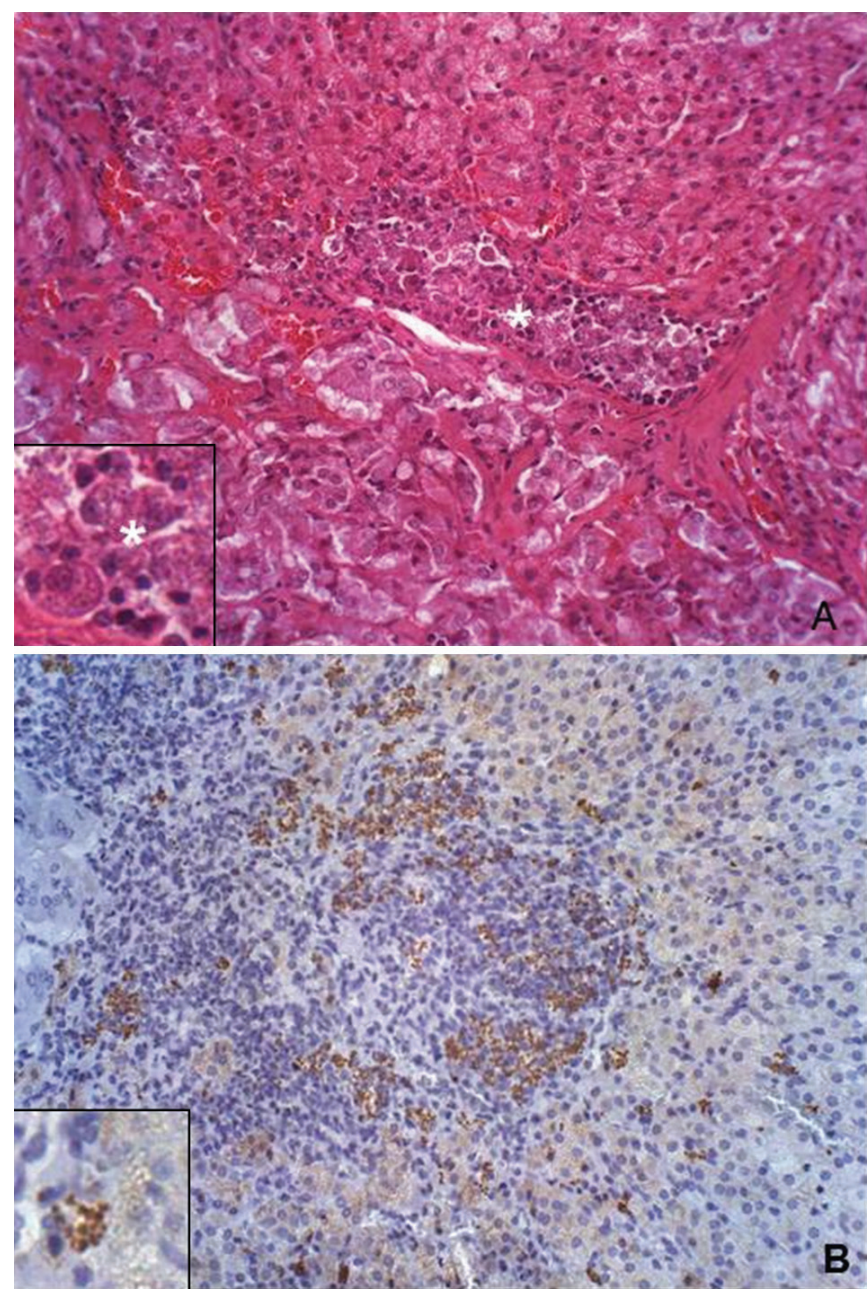

Figure 1. Photomicrograph of the adrenal gland of a dog that was symptomatic for visceral leishmaniasis. (A) Presence of granulomatous inflammation $\left(^{*}\right)$ in the cortical-medullary transition, composed by parasitized macrophages (hematoxylin and eosin; objective lens 40x). (B) Immunolabeling of amastigote forms of Leishmania spp. parasites in macrophages of the infiltrate that was present in the same region (streptavidin-peroxidase complex; objective lens 40x).

observed the parasite in the medullary layer and, less frequently, in the cortical layer of $22.7 \%$ of the 22 dogs evaluated. Some authors have suggested that high local concentration of antiinflammatory steroids in the adrenal cortex, such as cortisol, suppresses the local cell-mediated immune response, thus allowing the progressive multiplication of certain pathogenic microorganisms (JUBB et al., 2007; CARLTON; McGAVIN, 1998), as described for Histoplasma capsulatum in the adrenal gland's fasciculata layer Highland et al. (2011).

Cytokine receptors are widely expressed in several tissues, including the central nervous system. Pro-inflammatory cytokines (IL-1, IL-6 and TNF- $\alpha$ ) can influence a complex inflammatory response, thereby stimulating activity of the HPA axis and causing increased production of the corticotropin-releasing hormone (CRH) by the hypothalamus (TURNBULL; RIVIER, 1999). This induces the hypophysis to synthesize the adrenocorticotropic hormone (ACTH) and the adrenal glands to produce steroids, 
glucocorticoids, dehydroepiandrosterone (DHEA) and its sulfate ester (DHEAS) (SCHNEIDER et al., 1998). Some cytokines are capable of stimulating the HPA axis, thus increasing the plasma levels of glucocorticoids, as well as other adrenal steroids, such as DHEA (PÉREZ et al., 2009), which has an important immunomodulatory effect. While glucocorticoids contribute towards controlling excessive inflammatory processes and favor a Th2 response, DHEA stimulates a Th1 response, through stimulation of the activated $\mathrm{T}$ cells to produce IL-2 (HADDAD et al., 2002). In canine VL cases, some authors have reported an imbalance between the Th1 and Th2 responses (BARBIÉRI, 2006). Therefore, among animals with advanced disease, the predominant Th2 cytokine profile could contribute towards imbalance of the HPA axis, and the steroids produced by the adrenal gland could contribute towards the ineffective response that these animals presented when confronted with the parasite. Corrêa-de-Santana et al. (2006) observed, among rats experimentally infected with Trypanosoma cruzi, that the parasite modulates the hypothalamus-hypophysisadrenal axis, acting directly or indirectly, thereby interfering with the axis' homeostasis. The adrenal gland of these rats presented infiltration of macrophages and lymphocytes.

Among the dogs of the present study, the predominant leukocytes in the inflammatory infiltrate were plasmocytes and macrophages. There are no reports in the literature that suggest that the action of the glucocorticoids produced in the adrenal gland can affect the immune response, thus destroying circulating lymphocytes and inhibiting their mitosis in lymphoid organs (JUNQUEIRA; CARNEIRO, 2008). Immunosuppression in dogs with VL has been correlated with apoptosis or production of antiinflammatory cytokines (CORRÊA et al., 2007; MOREIRA et al., 2010, 2013). This may be directly related to adrenal gland infection (PAOLO JR; NOSANCHUK, 2006).

In other organs of the dogs studied, such as the popliteal lymph node, the parasite load was high among the symptomatic dogs (MOREIRA et al., 2010). However, it was not possible to observe any significant differences in the adrenal gland within the groups of infected dogs. This gland was possibly not the preferred organ for parasite multiplication, as seen in the spleen, lymph nodes, skin or bone marrow (unpublished data). However, once affected it could influence the immune system's activity, through the action of its glucocorticoid hormones. Moreover, the parasite possesses proven immune evasion mechanisms. These parasite and host mechanisms could act concomitantly and hinder the activation of cellular immune response and, thus, favor systemic survival of the protozoon Leishmania spp.

Endocrine adrenal activity influences other systems of the organism, as well as the immune system. Mineralocorticoids act on kidneys, stomach and sweat glands. These locations stimulate sodium absorption and can increase the systemic concentration of potassium (JUNQUEIRA; CARNEIRO, 2008). Renal insufficiency is one of the main findings in dogs with VL chronic evolution (COSTA et al., 2003). Interference by mineralocorticoids could aggravate the clinical condition of these animals, through the increase of circulating potassium level and, therefore, could cause severe heart problems.

\section{Conclusions}

Under the conditions of the present study, it was possible to conclude that the adrenal gland can be affected by infection caused by the Leishmania parasite, regardless of the clinical stage of VL. The most affected adrenal gland layers were the reticularis and, to a smaller extent, the medullary. The parasite's presence was always related to the presence of granulomatous inflammation in these locations. There were no statistical differences in adrenal parasite load between groups.

\section{Ethical standards}

The design for this study was approved by the Ethics and Animal Welfare Committee (CEBEA no. 000599-08), of FCAV/ UNESP, Jaboticabal, state of São Paulo, Brazil.

\section{Acknowledgements}

Financial assistance was provided by FAPESP (Fundação de Amparo à Pesquisa do Estado de Sáo Paulo, procedural number 2009/07815-4). P.R.R. Moreira (procedural number 2009/15736-7) and N.A.S. Rocha (procedural number 2007/01457-3) were FAPESP grantees. The authors wish to acknowledge Mrs. F.A. Ardisson for her histotechnical assistance.

\section{References}

Arlt W, Allolio B. Adrenal insufficiency. Lancet 2003; 361(9372): 18811893. http://dx.doi.org/10.1016/S0140-6736(03)13492-7

Brasil. Ministério da Saúde. Secretaria de Vigilância em Saúde. Departamento de Vigilância Epidemiológica. Manual de vigilância e controle da leishmaniose visceral. Brasília: Ministério da Saúde 2006; 122. Available from: http://dtr2001.saude.gov.br/editora/produtos/livros/ pdf/03_1193_M.pdf.

Banks WJ. Histologia Veterinária Aplicada. 2. ed. São Paulo: Manole; 1992.

Barbiéri CL. Immunology of canine leishmaniasis. Parasite Immunol 2006; 28(7): 329-337. PMid:16842269. http://dx.doi. org/10.1111/j.1365-3024.2006.00840.x

Bosworth DC. Reversible adrenocorticol insufficiency in fulminant meningococcemia. Arch Intern Med 1979; 139(7): 823-824. PMid:110279. http://dx.doi.org/10.1001/archinte.1979.03630440081027

Carvalho LOP, Calabrese KS, Costa SCG, Mendes VG, Silva APC, Barros ACE, et al. Leishmania (Leishmania) amazonensis: Experimental cutaneous leishmaniasis associated with systemic amyloidosis in mice. Exp Parasitol 2008; 120(1): 123-125. PMid:18601926. http://dx.doi. org/10.1016/j.exppara.2008.06.004

Carlton WW, McGavin MD. Patologia veterinária especial de Thomson. 2. ed. Porto Alegre: Armed; 1998.

Corrêa APFL, Dossi ACS, Vasconcelos RO, Munari DP, Lima VMF. Evaluation of transformation growth factor- $\beta_{1}$, interleukin-10, and interferon-g in male symptomatic and asymptomatic dogs naturally infected by Leishmania (Leishmania) chagasi. Vet Parasitol 2007; 143(3-4): 267-274. PMid:16979825. http://dx.doi.org/10.1016/j. vetpar.2006.08.023 
Corrêa-de-Santana E, Paez-Pereda M, Theodoropoulou M, Nihei OK, Gruebler Y, Bozza M, et al. Hypothalamus-pituitaryadrenal axis during Trypanosoma cruzi acute infection in mice. J Neuroimmunol 2006; 173(1-2): 12-22. PMid:16494952. http://dx.doi. org/10.1016/j.jneuroim.2005.08.015

Costa FAL, Goto H, Saldanha LCB, Silva SMMS, Sinhorini IL, Silva TC, et al. Histopathologic patterns of nephropathy in naturally acquired canine visceral leishmaniasis. Vet Pathol 2003; 40(6): 677-684. PMid:14608021. http://dx.doi.org/10.1354/vp.40-6-677

Davies E, Mackenzie SM. Extra-adrenal production of corticosteroids. Clin Exp Pharmacol Physiol 2003; 30(7): 437-445. http://dx.doi. org/10.1046/j.1440-1681.2003.03867.x

Engström L, Rosén K, Angel A, Fryberg A, Mackerlova L, Konsman $\mathrm{JP}$, et al. Systemic Immune Challenge Activates an Intrinsically Regulated Local Inflammatory Circuit in the Adrenal Gland. Endocrinology 2008; 149(4): 1436-1450. PMid:18174279. http://dx.doi. org/10.1210/en.2007-1456

Feitosa MM, Ikeda FA, Luvizotto MCR, Perri SHV. Aspectos clínicos de cães com leishmaniose visceral no município de Araçatuba - São Paulo (Brasil). Clin Vet 2000; 28: 36-44.

Ferrer L, Rabanal R, Domingo M, Ramos JA, Fondevila D. Identification of Leishmania donovani amastigotes in canine tissues by immunoperoxidase staining. Res Vet Sci 1998; 44(2): 194-196.

Gibson-Corley KN, Hostetter JN, Hostetter SJ, Mullin K, Ramer-Tait AE, Boggiatto PM, et al. Disseminated Leishmania infantum infection in two sibling foxhounds due to possible vertical transmission. Can Vet J 2008; 49(10): 1005-1008. PMid:19119370 PMCid:PMC2553493.

Ginn PE, Mensett JEKL, Rakick PM. Skin and appendages. In: Maxie MG, editor. Jubb, Kennedy, Palmer. Pathology of domestic animals. 5th ed. San Diego: Academic Press; 2007. p. 553-781.

Giunchetti RC, Martins-Filho OA, Carneiro CM, Mayrink W, Marques MJ, Tafuri WL, et al. Histopathology, parasite density and cell phenotypes of the popliteal lymph node in canine visceral leishmaniasis. Vet Immunol Immunopathol 2008; 121(1-2): 23-33. PMid:17723246. http://dx.doi. org/10.1016/j.vetimm.2007.07.009

Haddad JJ, Saadé NE, Safieh-Garabedian B. Cytokines and neuro - immune - endocrine interactions: a role for the hypothalamic - pituitary - adrenal revolving axis. J Neuroimmunol 2002; 133(1-2): 1-19. http://dx.doi.org/10.1016/ S0165-5728(02)00357-0

Hib J, Fiori D. Histologia Texto e Atlas. Rio de Janeiro: Guanabara Koogan; 2003.

Hofman V, Marty P, Perrin C, Saint-Paul MC, Fichoux Y, Michiels JF, et al. The histological spectrum of visceral leishmaniasis caused by Leishmania infantum MON- I in acquired immune deficiency syndrome. Hum Pathol 2000; 31(1): 75-84. http://dx.doi.org/10.1016/S00468177(00)80202-6

Jubb KVF, Kennedy PC, Palmer N. Pathology of domestic animals. 5th ed. San Diego: Academic Press, 2007.

Junqueira LC, Carneiro J. Histologia básica: texto e atlas. 11. ed. Rio de Janeiro: Guanabara Koogan; 2008.

Lima WG, Michalick MSM, Melo MN, Tafuri WL, Tafuri WL. Canine visceral leishmaniasis: a histopathological study of lymph nodes. Acta Trop 2004; 92(1): 43-53. PMid:15301974. http://dx.doi.org/10.1016/j. actatropica.2004.04.007

Longstaffe JA, Guy MW. Leishmaniasis in dogs. Vet Annual 1985; 25: 358367.
Moreira PRR, Bandarra MD, Magalhães GM, Munari DP, Machado GF, Prandini MM, et al. Influence of apoptosis on the cutaneous and peripheral lymph node inflammatory response in dogs with visceral leishmaniasis. Vet Parasitol 2013; 192(1-3): 149-157. PMid:23084537. http://dx.doi.org/10.1016/j.vetpar.2012.09.029

Moreira PRR, Vieira LM, Andrade MMC, Bandarra MB, Machado GF, Munari DP, et al. Immune response pattern of the popliteal lymph nodes of dogs with visceral leishmaniasis. Parasitol Res 2010; 107(3): 605-613. PMid:20499098. http://dx.doi.org/10.1007/s00436-010-1902-2

Paolo WF Jr, Nosanchuk JD. Adrenal infections. Int J Infect Dis 2006; 10(5): 343-353. PMid:16483815. http://dx.doi.org/10.1016/j. ijid.2005.08.001

Pereira RM, Guerra-Júnior G, Tresoldi AT. Adrenal function in 23 children with paracoccidioidomycosis. Rev Inst Med Trop Sao Paulo 2006; 48(6): 333-336. PMid:17221130. http://dx.doi. org/10.1590/S0036-46652006000600006

Pereira ND. Parasitologia humana. 10. ed. São Paulo: Atheneu; 2000.

Pérez AN, Bottasso O, Savino W. The impact of infectious diseases upon euroendocrine circuits. Neuroimmunomodulation 2009; 16(2): 96-105. PMid:19212129. http://dx.doi.org/10.1159/000180264

Pumarola M, Brevik L, Bradiola J, Vargas A, Domingo M, Ferrer L. Canine leishmaniasis associated with sistemic vasculitis in two dogs. J Comp Pathol 1991; 105(3): 279-286. http://dx.doi.org/10.1016/ S0021-9975(08)80196-X

Ruiz MR, Quiñones AG, Diaz NL, Tapia FJ. Acute immobilization stress induces clinical and neuroimmunological alterations in experimental murine cutaneous leishmaniasis. Br J Dermatol 2003; 149(4): 731-718. PMid:14616363. http://dx.doi.org/10.1046/j.1365-2133.2003.05604.x

Schneider H, Pitossi F, Balschun D, Wagner A, Del Rey A, Besedovsky HO. A neuromodulatory role of interleukin-1 beta in the hippocampus. Proc Natl Acad Sci USA 1998; 95(13): 7778-7783. PMid:9636227 PMCid:PMC22755. http://dx.doi.org/10.1073/pnas.95.13.7778

Schnur L, Zuckerman A, Montilio B. Dissemination of Leishmanias to the organs of syrian hamster following intrasplenic inoculation of promastigotes. Exp Parasitol 1973; 34(3): 432-447. http://dx.doi org/10.1016/0014-4894(73)90103-3

Highland MA, Chaturvedi S, Perez M, Steinberg H, Wallace R. Histologic and molecular identification of disseminated Histoplasma capsulatum in a captive brown bear (Ursus arctos). J Vet Diagn Invest 2011; 23(4): 764-769. http://dx.doi.org/10.1177/1040638711406976.

Tafuri WL, De Oliveira MR, Melo MN, Tafuri WL. Canine visceral leishmaniosis: a remarkable histopathological picture of one case reported from Brazil. Vet Parasitol 2001; 96(3): 203-212. http://dx.doi. org/10.1016/S0304-4017(00)00436-2

Tafuri WL, Santos RL, Arantes RME, Gonçalves R, Melo MN, Michalick MSM, et al. An alternative immunohistochemical method for detecting Leishmania amastigotes in paraffin-embedded canine tissues. J Immunol Methods 2004; 292(1-2): 17-23. PMid:15350508. http://dx.doi. org/10.1016/j.jim.2004.05.009

Tosoni A, Nebuloni M, Ferri A, Bonetto S, Antinori S, Scaglia $\mathrm{M}$, et al. Disseminated microsporidiosis caused by Encephalitozoon cuniculi III (dog type) in an Italian AIDS patient: a retrospective study. Mod Pathol 2002; 15(5): 577-583. PMid:12011264. http://dx.doi. org/10.1038/modpathol.3880566

Toplu N, Aydogan A. An immunohistochemical study in cases with usual and unusual clinicopathological findings of canine visceral leishmaniosis. 
Parasitol Res 2011; 109(4): 1051-1057. PMid:21479577. http://dx.doi. org/10.1007/s00436-011-2345-0

Turnbull AV, Rivier CL. Regulation of the hypothalamic-pituitaryadrenal axis by cy-tokines: actions and mechanisms of action. Physiol Rev 1999; 79(1): 1-71. PMid:9922367.
Virella G. Infections and Immunity In: Virella G. Medical immunology. New York: Marcel Dekker; 2001. p. 259-278.

Virella G, Bierer BE. The induction of an immune response: antigens, lymphocytes, and accessory cells. In: Virella G. Medical Immunology New York: Marcel Dekker; 2001. p. 51-76. 